УДК 633.15:631.51.021:631.8:631.67 (477.7)

DOI https://doi.org/10.32848/agrar.innov.2021.5.20

\title{
ПРОДУКТИВНІСТЬ КУКУРУДЗИ ЗА МІНІМІЗОВАНОГО ОБРОБІТКУ ҐРУНТУ ТА ОРГАНО-МІНЕРАЛЬНИХ СИСТЕМ УДОБРЕННЯ НА ЗРОШЕННІ ПІВДНЯ УКРАЇНИ
}

\author{
ВОЖЕГОВА Р.А. - доктор сільськогосподарських наук, профессор, \\ академік Національної академії аграрних наук України \\ https://orcid.org/0000-0002-3895-5633 \\ Інститут зрошуваного землеробства Національної академії аграрних наук України \\ ICAКОВА Г.М. - кандидат сільськогосподарських наук \\ https://orcid.org/0000-0002-1088-1302 \\ МАЛЯРЧУК А.С. - кандидат сільськогосподарських наук \\ https://orcid.org/0000-0001-5845-269X \\ Інститут зрошуваного землеробства Національної академії аграрних наук України \\ КОТЕЛЬНИКОВ Д.І. - кандидат сільськогосподарських наук \\ https://orcid.org/0000-0002-8889-8841 \\ Фермерське господарство «ЮКОС і К» \\ ГАЛЬЧЕНКО Н.М. - кандидат сільськогосподарських наук \\ https://orcid/0000-0002-1717-5101 \\ Асканійська державна сільськогосподарська дослідна станція \\ Інституту зрошуваного землеробства Національної академії аграрних наук \\ України
}

Постановка проблеми. Одна з найважливіших зернових культур світу, яка серед зернових займає друге місце після пшениці озимої, а за врожайністю зерна перевищує всі зернові культури, - кукурудза. Проте отримання високих урожаїв можливе лише за надійного захисту посівів від бур'янів у зв'язку з низьким рівнем конкурентної здатності культури. Бур'яни можуть знижувати врожайність кукурудзи на 20-70\%. Утрати врожаю залежать від кількості, видового складу та тривалості присутності бур'янів у посіві.

Систематичне застосування гербіцидів у посівах сільськогосподарських культур не призвело в Україні до зменшення актуальної і потенційної забур'яненості полів. Проте основою захисту посівів від бур'янів залишилося застосування комплексу агротехнічних заходів, зокрема й основного обробітку ґрунту. Наукові дослідження і практика дають підстави вважати, що основний обробіток є найбільш дієвим заходом контролю рівня присутності бур'янів у агрофрітоценозах [1].

Аналіз останніх досліджень і публікацій. Незважаючи на широке впровадження сучасних високоефективних гербіцидів, бур'яни й надалі залишаються шкідливими об'єктами, які знижують урожай зерна кукурудзи більше ніж на третину [2; 3]. Бур'яни не можна розглядати ізольовано, адже вони є рівноправними компонентами, а зміна їх чисельності та складу зумовлюється, насамперед, екологічними змінами, технологією вирощування, попередниками й особливостями окремих способів обробітку ґрунту [4; 5].

Багатьма науковцями доведено, що післязбиральне лущення стерні з подальшою оранкою на зяб $є$ найбільш ефективним заходом захисту посівів від бур'янів за рахунок заорювання насіння у нижні шари ґрунту, у результаті чого воно не проростає [6;7]. Проте, за даними [8], поглиблення оранки від 20 до 30 см забезпечує зниження забур'яненості посівів кукурудзи вдвічі. Водночас Я.П. Цвей не поділяє такої думки і вважає, що заоране на певну глибину чи рівномірно розміщене у ґрунтовому профрілі насіння бур'янів під час чергового обробітку плугом знову виноситься на поверхню у зону можливого їх проростання [9]. Приблизно такої ж думки дотримуються й інші вчені, які стверджують, що застосування безполицевого обробітку ґрунту за умови щорічного внесення гербіцидів не підвищує забур'яненості посівів порівняно із беззмінною оранкою [10; 11]. Отже, серед науковців немає одностайної думки щодо впливу системи обробітку ґрунту на забур'яненість посівів, а продовження експериментальних досліджень із цього питання й надалі залишатиметься актуальним.

Мета статті. Метою досліджень було встановлення впливу різних систем, способів і глибини основного обробітку та удобрення на показники забур'яненості посівів і продуктивність кукурудзи в сівозміні на зрошуваних землях Півдня України.

Матеріали та методика досліджень. Дослідження проводилися протягом 2016-2019рр. у чотирипільній зерно-просапній сівозміні з таким чергуванням культур: кукурудза на зерно, ячмінь озимий + гірчиця сарептська на сидерат, соя, пшениця озима + гірчиця сарептська на сидерат на дослідних полях Асканійської державної сільськогосподарської дослідної станції Інституту зрошуваного землеробства НААН України, яка розташована в зоні дії Каховської зрошувальної системи. На експериментальне дослідження поставлено два фактори: основний обробіток ґрунту та органо-мінеральні системи удобрення.

Фактор А (основний обробіток ґрунту):

1. Оранка під кукурудзу на глибину 28-30 см у системі диференційованого основного обробітку ґрунту (контроль).

2. Дисковий обробіток на 12-14 см у системі безполицевого мілкого одноглибинного обробітку.

3. Чизельний обробіток на 28-30 см у системі безполицевого різноглибинного обробітку.

4. Нульова система основного обробітку із сівбою спеціальними сівалками в попередньо необроблений ґрунт.

Дослідження проводилися на тлі трьох органо-мінеральних систем удобрення з різними дозами внесення мінеральних добрив під кукурудзу (Фактор В): 
1. Органо-мінеральна з внесенням $\mathrm{N}_{120} \mathrm{P}_{40}+$ післяжнивні рештки + сидерат.

2. Органо-мінеральна з внесенням $\mathrm{N}_{150} \mathrm{P}_{40}+$ післяжнивні рештки + сидерат.

3. Органо-мінеральна з внесенням $\mathrm{N}_{180} \mathrm{P}_{40}+$ післяжнивні рештки + сидерат.

4. Органо-мінеральна з внесенням $\mathrm{N}_{180} \mathrm{P}_{40}+$ післяжнивні рештки.

Ґрунт дослідного поля темно-каштановий середньо-суглинковий із низькою забезпеченістю азотом та середньою - рухомим фоссрором і обмінним калієм. Режим зрошення забезпечував підтримання передполивного порогу зволоження під посівами культур сівозміни на рівні 70-75\% НВ у шарі ґрунту 0-50 см.

Під час експерименту використовували польовий, кількісно-ваговий, візуальний, лабораторний, розрахунково-порівняльний, математично-статистичний методи та загальновизнані в Україні методики і методичні рекомендації [12].

Результати досліджень. Результати досліджень, проведені протягом 2016-2019 рр., дають змогу стверджувати, що за оранки на 28-30 см у системі диференційованого обробітку ґрунту (контроль) забур'яненість посівів кукурудзи залежно від систем удобрення коливалася в межах 7-21 шт./м² з показниками вегетативної маси на рівні $16,5-53,6$ r/M² та в середньому по фактору

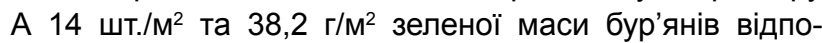
відно. Заміна оранки чизельним розпушуванням на таку саму глибину в системі різноглибинного безполицевого обробітку протягом ротації сівозміни сприяла зниженню забур'яненості посівів кукурудзи порівняно з контролем на 40\% за кількістю бур'янів та на $19,7 \%$ за масою

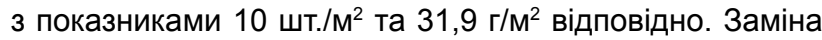
оранки дисковим розпушуванням на глибину 12-14 см на тлі одноглибинного мілкого безполицевого обробітку призвела до підвищення забур'яненості посівів у середньому по фактору А на 42,9\% за кількістю бур'янів та на 36,2\% за масою, з показниками 20 шт./м² та 52,0 г/м² відповідно.

Найвищою забур'яненість посівів кукурудзи в середньому по фрактору А (25 шт./м² за кількістю та 298,8 г/м²3a масою) формувалася за нульового обробітку ґрунту у сівозміні, що вище, ніж на контролі, відповідно на $78,6 \%$ за кількістю та в 7,82 рази за масою.

На забур'яненість посівів кукурудзи істотно впливали системи удобрення. Так, залежно від системи основного обробітку за дози добрив $\mathrm{N}_{120} \mathrm{P}_{40}+$ післяж- нивні рештки + сидерат забур'яненість посівів кукурудзи коливалася в межах 7-18 шт./м² з показниками

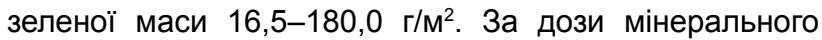
добрива $\mathrm{N}_{150} \mathrm{P}_{40}$ + післяжнивні рештки + сидерат забур'яненість посівів у середньому по фактору В зросла до

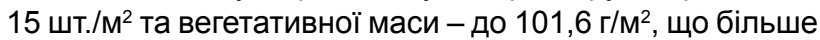
порівняно 3 контролем на $36,4 \%$ та $55,1 \%$ відповідно. Подальше збільшення дози азотного добрива $\mathrm{N}_{180} \mathrm{P}_{40}+$ післяжнивні рештки + сидерат сприяло подальшому під-

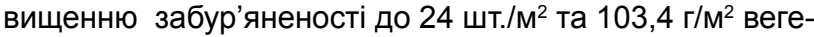
тативної маси, що більше порівняно з дозою $\mathrm{N}_{120} \mathrm{P}_{40}+$ післяжнивні рештки + сидерат на $63,6 \%$ за кількістю та на $57,9 \%$ - за масою (табл. 1).

Також необхідно відзначити вплив сидерації на забур'яненість посівів кукурудзи. Вирощування гірчиці сарептської на сидерат у післяжнивних посівах після пшениці озимої із загортанням ії̈ в ґрунт знаряддями з різною конструкцією робочих органів на певну глибину мало істотний вплив на чисельність та масу бур'янів з одиниці площі. За оранки на глибину 28-30 см у системі диференційованого обробітку ґрунту в сівозміні та системи удобрення $\mathrm{N}_{180} \mathrm{P}_{40}+$ післяжнивні рештки + сидерат забур'яненість посівів була меншою на 23,5\%, а вегетативна маса бур'янів - на $12,1 \%$ порівняно із безсидеральним фоном ( $\mathrm{N}_{180} \mathrm{P}_{40}+$ післяжнивні рештки). За системи мілкого одноглибинного безполицевого обробітку кількість бур'янів за використання сидерації зменшилася на $36,4 \%$, проте вегетативна маса залишилася на тому самому рівні.

Використання сидерації на тлі безполицевого різноглибинного обробітку не вплинуло на кількість бур'янів у досліді, водночас вегетативна маса зменшилася на $26,1 \%$, за нульового обробітку кількість бур'янів зменшилася на $47,8 \%$, а вегетативна маса - на $61,7 \%$. Необхідно відзначити, що в середньому по фрактору А застосування сидеральної культури сприяє змен-

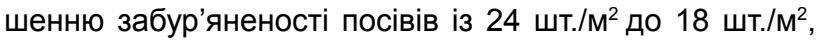

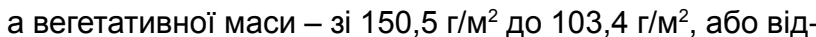
повідно на $33,3 \%$ та $45,6 \%$.

Аналіз показників урожайності зерна кукурудзи в середньому за 2016-2019 рр. досліджень свідчить, що за оранки на 28-30 см у системі диференційованого обробітку ґрунту врожайність зерна за різних систем удобрення коливалася в межах 9,81-11,05 т/га та 10,41 т/га в середньому по фактору А. Заміна оранки чизельним розпушуванням на таку ж саму глибину в системі різноглибинного безполицевого обробітку та зменшення глибини

Таблиця 1 - Забур'яненість посівів кукурудзи за різних систем основного обробітку ґрунту та удобрення (середнє за 2016-2019 рр.)

\begin{tabular}{|c|c|c|c|c|c|c|c|c|c|c|}
\hline \multirow{3}{*}{$\begin{array}{c}\text { Система основного обро- } \\
\text { бітку ґрунту (А) }\end{array}$} & \multicolumn{10}{|c|}{ Система удобрення (В) } \\
\hline & \multicolumn{2}{|c|}{$\mathrm{N}_{120} \mathrm{P}_{40}+$ сидерат } & \multicolumn{2}{|c|}{$\mathbf{N}_{150} \mathbf{P}_{40}+$ сидерат } & \multicolumn{2}{|c|}{$\mathrm{N}_{180} \mathrm{P}_{40}+$ сидерат } & \multicolumn{2}{|c|}{$\mathbf{N}_{180} P_{40}$} & \multicolumn{2}{|c|}{$\begin{array}{c}\text { В середньому } \\
\text { (A) }\end{array}$} \\
\hline & шт./M² & $r / M^{2}$ & шт./M² & $\Gamma / M^{2}$ & шт. / $\mathbf{M}^{2}$ & $\Gamma / M^{2}$ & шт. $/ \mathbf{M}^{2}$ & $r / M^{2}$ & шт./M² & $r / M^{2}$ \\
\hline Диференціо-вана & 7 & 16,5 & 10 & 35 & 17 & 47,8 & 21 & 53,6 & 14 & 38,2 \\
\hline Мілка одноглибинна & 11 & 37,0 & 16 & 49 & 22 & 59 & 30 & 62,9 & 20 & 52,0 \\
\hline Різноглибинна безполицева & 9 & 28,6 & 9 & 32,2 & 10 & 29,5 & 10 & 37,2 & 10 & 31,9 \\
\hline Нульова & 18 & 180 & 23 & 290 & 23 & 277,2 & 34 & 448,1 & 25 & 298,8 \\
\hline У середньому (В) & 11 & 65,5 & 15 & 101,6 & 18 & 103,4 & 24 & 150,5 & & \\
\hline \multicolumn{4}{|l|}{$\mathrm{HIP}_{05}(\mathrm{~A})=0,8$ шт./$/ \mathrm{M}^{2} ; 4,3 \mathrm{r} / \mathrm{M}^{2}$} & \multicolumn{7}{|c|}{$\mathrm{HIP}_{05}(\mathrm{~B})=0,8$ шт./$/ \mathrm{M}^{2} ; 3,8$ г/$/ \mathrm{M}^{2}$} \\
\hline
\end{tabular}


Таблиця 2 - Урожайність зерна кукурудзи за різних систем основного обробітку ґрунту та удобрення, у середньому за 2016-2019 рр., т/га

\begin{tabular}{|c|c|c|c|c|c|}
\hline \multirow{2}{*}{$\begin{array}{c}\text { Система основного обробітку } \\
\text { ґрунту (А) }\end{array}$} & \multicolumn{5}{|c|}{ Доза добрив (В) } \\
\hline & $\begin{array}{l}\mathrm{N}_{120} \mathrm{P}_{40}+ \\
\text { сидерат }\end{array}$ & $\begin{array}{l}\mathrm{N}_{150} \mathrm{P}_{40}+ \\
\text { сидерат }\end{array}$ & $\begin{array}{l}\mathrm{N}_{180} \mathrm{P}_{40}+ \\
\text { сидерат }\end{array}$ & $\mathrm{N}_{180} \mathrm{P}_{40}$ & $\begin{array}{c}\text { в середньому по } \\
\text { фактору A }\end{array}$ \\
\hline Диференційована 28-30 см (о) & 9,81 & 10,45 & 11,05 & 10,34 & 10,41 \\
\hline Мілка одноглибинна 12-14 (д) & 9,54 & 10,31 & 10,94 & 10,27 & 10,27 \\
\hline Різноглибинна безполицева 28-30 (4) & 10,24 & 10,95 & 11,69 & 10,83 & 10,93 \\
\hline Нульова & 8,42 & 8,82 & 9,05 & 8,55 & 8,71 \\
\hline У середньому по фактору В & 9,50 & 10,13 & 10,68 & 10,00 & \\
\hline $\mathrm{HIP}_{05}(\mathrm{~A})=0,48 \mathrm{~T} /$ га & \multicolumn{5}{|c|}{$\mathrm{HIP}_{05}=0,14 \mathrm{~T} / \mathrm{ra}$} \\
\hline
\end{tabular}

основного обробітку до 12-14 см у системі довготривалого мілкого безполицевого обробітку не мала істотного впливу на рівень урожайності HIP $_{05}(A)=0,48$ т/га. Водночас істотний недобір урожаю відзначено за нульового обробітку, де показники коливалися в межах 8,42-9,05 т/га та були меншими порівняно з контролем у середньому по фактору А на $16,3 \%$. Водночас необхідно відзначити зміни продуктивності залежно від системи удобрення. Так, на фоні $\mathrm{N}_{120} \mathrm{P}_{40}+$ післяжнивні рештки + сидерат урожайність коливалася в межах 8,42-10,24 т/га. Поліпшення азотного живлення у варіанті $\mathrm{N}_{150} \mathrm{P}_{40}+$ післяжнивні рештки + сидерат сприяло збільшенню врожайності в середньому по фактору В до 10,13 т/га, або на 6,6\% порівняно з контролем, а найвищий рівень продуктивності отримано у варіанті з внесенням $\mathrm{N}_{180} \mathrm{P}_{40}+$ післяжнивні рештки + сидерат із показником 10,68 т/га, що більше порівняно з варіантом $\mathrm{N}_{120} \mathrm{P}_{40}+$ післяжнивні рештки + сидерат на 12,4\% (табл. 2).

Також слід відзначити вплив сидеральної культури на показники продуктивності кукурудзи. Так, використання сидерації на тлі диференційованої системи основного обробітку та однакового мінерального живлення призвело до збільшення врожайності з 10,34 до 11,05 т/га, або на 6,9\%. За мілкої одноглибинної безполицевої системи основного обробітку ґрунту врожайність від використання сидерації збільшилася на $6,5 \%$. Найбільший приріст врожайності було отримано за системи безполицевого різноглибинного обробітку з 10,83 до 11,69 т/га, або на $7,9 \%$, а найменший за нульового обробітку - лише на 5,8\%. У середньому по фактору В використання сидерації збільшило продуктивність кукурудзи з 9,50 до 10,68 т/га, або на 12,4\%.

Висновки. Дослідженнями встановлено, що заміна оранки чизельним розпушуванням на 28-30 см у системі різноглибинного безполицевого обробітку зменшило забур'яненість посівів кукурудзи порівняно з контролем на $40 \%$ за кількістю бур'янів та на $19,7 \%$ вегетатив-

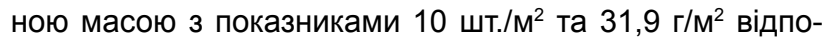
відно. Максимальну забур'яненість у досліді в середньому по фрактору А (25 шт./M ${ }^{2}$ за кількістю бур'янів та 298,8 г/м² за вегетативною масою) було відзначено за нульового обробітку ґрунту у сівозміні, що збільшувало їх кількість на 78,6\%, а вегетативну масу в 7,82 рази порівняно з контролем.

Водночас у середньому по фактору В застосування сидеральної культури зменшує забур'яненість на 33,3\% за кількістю та 45,6\% за вегетативною масою та сприяє підвищенню продуктивність кукурудзи на 13,7\%.
Системи диференційованого, мілкого одноглибинного та різноглибинного безполицевого обробітку ґрунту забезпечують однаковий рівень урожайності в межах 8,71-10,93 т/га. Водночас істотний недобір урожайності було отримано за нульового обробітку, де показники були менше порівняно з контролем у середньому по фактору А на 16,3\%.

\section{СПИСОК ВИКОРИСТАНОÏ ЛІТЕРАТУРИ:}

1. Науково-практичні рекомендації з технології вирощування кукурудзи в умовах зрошення Південного Степу України / Р.А. Вожегова та ін. Херсон : Грінь Д.С., 2015. 104 c.

2. Цилюрик О.І. Вплив мульчувального обробітку ґрунту на поживний режим чорнозему в посівах ячменю ярого. Вісник Дніпровського державного аграрно-економічного університету. 2017. № 3(45). С. 23-31.

3. Мальцев В.Т., Дьяченко Е.Н. Влияние способов основной обработки почвы и удобрений на содержание подвижного азота в серой лесной почве и продуктивность севооборота. Достижения науки и техники АПК. 2011. № 12. С. 8-11.

4. Примак І.Д., Купчик В.І., Колесник Т.В. Зміна агрохімічних властивостей чорнозему типового за різних систем основного обробітку ґрунту й удобрення в Центральному Лісостепу України. Вісник Полтавської державної аграрної академії. 2012. № 3. C. 26-31.

5. Котоврасов И.П. Влияние механической обработки на плодородие мощного малогумусного чернозема в Лесостепи Украины. Минимализация обработки почвы. Москва : Колос, 1984. С. 106-115.

6. Дроговоз С. Плодородие почвы при отвальной и почвозащитной обработках. Научные основы севооборотов и обработки почвы в Восточной Сибири. Иркутск, 1975. С. 89-95.

7. Цандур М.О. Наукові основи землеробства Південного Степу України. Одеса : Папірус, 2006. $180 \mathrm{c}$.

8. Формирование урожайности культур при различных видах и структуре севооборота / Я.П. Цвей и др. Сахарная свекла. 2018. № 8. С. 19-22.

9. Цвей Я.П. Родючість ґрунтів і продуктивність сівозмін. Київ : КОМПРИНТ, 2014. 416 с.

10. Наукові основи землеробства: підручник/І.Д. Примак та ін. Біла Церква : БДАУ, 2005. 408 с.

11. Леонець В.О. Екологічні наслідки сучасної деградації природних і антропогенних ландшафтів та основні напрями охорони земель. Землевпорядний вісник. 1998. № 3. С. 26-29. 
12. Методика польових і лабораторних досліджень на зрошуваних землях / Р. А. Вожегова та ін. Херсон : Грінь Д.С., 2014. 286 с.

\section{REFERENCES:}

1. Vozhegova, R.A., Gozh, O.A. \& Marchenko T.Yu., et al. (2015). Naukovo-praktychni rekomendatsiyi z tekhnolohiyi vyroshchuvannya kukurudzy $v$ umovakh zroshennya Pivdennoho Stepu Ukrayiny [Scientific and practical recommendations for the technology of growing corn under irrigation of the Southern Steppe of Ukraine]. Kherson : Grin D.S. [in Ukrainian].

2. Tsilyurik, O.I. (2017). Vplyv mulchuvalnoho obrobitku gruntu na pozhyvnyi rezhym chornozemu $v$ posivakh yachmeniu yaroho [Influence of mulching tillage on the nutrient regime of chernozem in spring barley crops]. Visnyk dniprovskoho derzhavnoho ahrarnoekonomichnoho universytetu - Bulletin of the Dnieper State Agrarian Economic University, 3 (45), 23-31 [in Ukrainian].

3. Maltsev, V.T. \& Dyachenko, E.N. (2011). Vliyanie sposobov osnovnoy obrabotki pochvyi i udobreniy na soderzhanie podvizhnogo azota $v$ seroy lesnoy pochve i produktivnost sevooborota [Influence of basic tillage methods and fertilizers on the content of mobile nitrogen in gray forest soil and crop rotation productivity]. Dostizheniya nauki i tehniki APK - Achievements of science and technology of agro-industrial complex, 12, 8-11 [in Russian].

4. Primak, I.D., Kupchik, V.I. \& Kolesnik, T.V. (2012). Zmina ahrokhimichnykh vlastyvostei chornozemu typovoho za riznykh system osnovnoho obrobitku gruntu y udobrennia $v$ Tsentralnomu Lisostepu Ukrainy [Change of agrochemical properties of chernozem typical for different systems of basic tillage and fertilizer in the Central Forest-Steppe of Ukraine]. Visnyk Poltavskoi derzhavnoi ahrarnoi akademii - Bulletin of the Poltava State Agrarian Academy, 3, 26-31 [in Ukrainian].

5. Kotovrasov, I.P. (1984). Vliyanie mehanicheskoy obrabotki na plodorodie moschnogo malogumusnogo chernozema $v$ Lesostepi Ukrainyi [Influence of mechanical tillage on the fertility of powerful lowhumus chernozem in the Forest-Steppe of Ukraine] Minimalizatsiya obrabotki pochvy - Minimization of tillage. 106-115 [in Russian].

6. Drogovoz, S. (1975). Plodorodie pochvyi pri otvalnoy i pochvozaschitnoy obrabotkah [Soil fertility during dumping and soil protection tillage]. Nauchnyie osnovyi sevooborotov i obrabotki pochvyi v Vostochnoy Sibiri Scientific bases of crop rotations and tillage in Eastern Siberia, 89-95 [in Russian].

7. Tsandur, M.O. (2006). Naukovi osnovy zemlerobstva Pivdennoho Stepu Ukrainy [Scientific bases of agriculture of the Southern Steppe of Ukraine]. Odesa: Papyrus [in Ukrainian].

8. Tsvey, Ya.P., Bondar, S.A., Kalibabchuk, T.V., Kostenko, S.S. \& Karpenko Ya.L. (2018). Formirovanie urozhaynosti kultur pri razlichnyih vidah i strukture sevooborota [Formation of crop yields in different types and structure of crop rotation]. Saharnaya svekla Sugar beet, 8. 19-22 [in Russian].

9. Tsvey, Ya.P. (2014). Rodiuchist gruntiv i produktyvnist sivozmin [Robustness of runts and productivity of growth]. Kiev : KOMPRINT [in Ukrainian].
10. Primak, I.D. et al. (2005). Science bases of farming Bila Tserkva: BDAU [in Ukrainian]

11. Leonets, V.O. (1998). Ekolohichni naslidky suchasno dehradatsii pryrodnykh i antropohennykh landshaftiv ta osnovni napriamy okhorony zemel [Ecological inheritance of the recent degradation of natural and anthropogenic landscapes and the main direct protection of lands]. Zemlevporiadnyi visnyk - Land-row visnik, 3. 26-29 [in Ukrainian].

12. Vozhehova, R.A. \& Lavrynenko, Yu.O. (2014). Metodyka pol'ovykh i laboratornykh doslidzhen na zroshuvanykh zemlyakh [Methods of field and laboratory research on irrigated lands]. Kherson : Hrin D.S. [in Ukrainian].

Вожегова Р.А., Ісакова Г.М., Малярчук А.С., Котельников Д.І., Гальченко Н.М.

Продуктивність кукурудзи за мінімі-зованого обробітку ґрунту та органо-мінеральних систем удобрення на зрошенні Півдня України

У статті відображено результати досліджень із вивчення показників забур'яненості та продуктивності кукурудзи залежно від різних систем основного обробітку ґрунту та удобрення і подальшого впливу на показники продуктивності культури у сівозміни в зрошуваних умовах Півдня України. Мета. Метою досліджень було визначення впливу основного обробітку ґрунту, різних систем удобрення та сидерації на забур'яненість посівів кукурудзи та подальшого впливу на його продуктивність. Методи. Під час експерименту використовували польовий, кількісно-ваговий, візуальний, лабораторний, розрахунково-порівняльний, математично-статистичний методи та загальновизнані в Україні методики і методичні рекомендації. Дослідження проводилися протягом 2016-2019 рр. на дослідних полях Асканійської ДСДС I3З НААН України. Результати. Дослідженнями встановлено, що заміна оранки чизельним розпушуванням на 28-30 см у системі різноглибинного безполицевого обробітку зменшила засміченість посівів кукурудзи порівняно з контролем на 40\% за кількістю бур'янів та на 19,7\% за накопиченням вегетативної маси з показниками 10 шт./м²

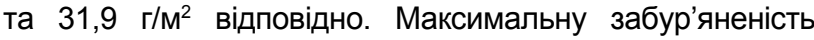
у досліді в середньому по фактору А (25 шт./M² за кількістю бур'янів та 298,8 г/м² за накопиченням вегетативної маси) було відзначено за нульового обробітку ґрунту у сівозміні, що збільшувало їх кількість на $78,6 \%$ а вегета-тивну масу в 7,82 рази порівняно з контролем. Водночас у середньому по фактору В застосування сидеральної культури зменшує забур'яненість на 33,3\% за кількістю та 45,6\% за вегетативною масою, підвищуючи продук-тивність кукурудзи на 13,7\%. Отримано однаковий рівень урожайності за систем диференційованого, мілкого одно-глибинного та різноглибинного безполицевого обробітку ґрунту 8,71-10,93 т/га. Водночас істотний недобір уро-жайності було отримано за нульового обробітку, де показ-ники були менше порівняно з контролем у середньому по фактору А на 16,3\%.

Ключові слова: кукурудза, система основного обро-бітку ґрунту, урожайність, забур'яненість.

Vozhehova R.A., Isakova H.M., Maliarchuk A.S., Kotelnikov D.I., Galchenko N.M. Productivity of corn at the minimized soil tillage and organic and mineral systems of fertilizer on irrigation of south of Ukraine

In the article the results of researches are represented on the study of indexes of impurit and productivity of corn depending on the different systems of basic soil 
tillage and fertilizer and further influence on the indexes of the productivity of culture in a crop rotation in the irrigated terms of south of Ukraine. The purpose of researches was determination of influence of basic soil tillage, different systems of fertilizer and sideration on the impurit of sowing of corn and further influence on his productivity. Methods. During an experiment used the field, in-gravimetric, visual, laboratory, calculation-comparative, mathematicallystatistical methods and confessedly in Ukraine methods and methodical recommendations. Researches were conducted during 2016-2019 on the experienced fields of Askanian SARS of IIA of NAAS. Results. It is set researches, that substituting of ploughing the chisel loosening by a $28-30 \mathrm{~cm}$ in the system of plowless on different depth tillage decreased the impurit of sowing of corn as compared to control on $40 \%$ on the amount of weeds and on $19,7 \%$ on the accumulation of vegetative mass with indexes 10 pieces $/ \mathrm{m}^{2}$ and $31,9 \mathrm{~g} / \mathrm{m}^{2}$ accordingly. Maximal impurit in experience on the average on a factor A (25 pieces $/ \mathrm{m}^{2}$ for the amounts of weeds and $298,8 \mathrm{~g} / \mathrm{m}^{2}$ on the accumulation of vegetative mass) it was marked at a no till in a crop rotation, that increased their amount on $78,6 \%$, and vegetative mass in 7,82 time as compared to control. At the same time, on the average on a factor In application of siderate culture diminishes an impurit on 33,3 for amounts and $45,6 \%$ on vegetative mass, promoting the productivity of corn on $13,7 \%$. The identical level of the productivity is got at the systems to the differentiated, plowless singledepth and different depth soil tillage 8,71-10,93 t/ha. At the same time the substantial shortage of the productivity was got at a no tillage, where indexes were less than as compared to control on the average on a factor A on $16,3 \%$

Key words: corn, system of basic soil tillage, productivity, impurity. 